\title{
Global Solidarity as a Response to Our Common Humanity
}

\author{
SAFRO KWAME \\ Lincoln University, Pennsylvania, USA (kwame@lincoln.edu)
}

In 'Existence and Heritage,' which was published by the State University of New York Press in 2015 as part of its series on philosophy and race, Tseney Serequeberhan sets out on what he calls hermeneutic explorations of African and Continental philosophies. It uses Hans-Georg Gadamer to reflect on different traditions; and a reading of Martin Heidegger and Karl Marx for postcolonial Africa. He concludes with a conception of thought as openness, drawn from his reading of Frant: Fanon. In it, he reveals many of his personal sympathies and antipathies; some of which, even though acceptable to some or even many, appear as assumptions or premises in the book with little or no argumentation. Overall, 'Existence and Heritage' is an interesting book that is worth reading. If the aim is to provoke us into debating some of the claims mentioned above or the objective of African philosophy, it does that. If, however, the aim is to convince us to embrace Serequeberban's own views enumerated above, then I am afraid the book. falls short.

Keywords: Philosophy; Africa; African philosophy, postcolonial Africa; African and European continental philosophies; comparative philosophy

TSENEY SEREQUEBERHAN, Existence and Heritage, New York, New York Press 2015, 185 pages.

In Tseney Serequeberhan's Existence and Heritage, which was published as part of a series on philosophy and race, he sets out on what he calls hermeneutic explorations of African and Continental philosophies.

The book operates with assumptions or premises which are not sufficiently backed up by argumentation. In it, he reveals many of his personal sympathies and antipathies; some of which, even though acceptable to some or even many, appear as assumptions or premises in the book with little or no argumentation.

Here are some examples: "The United States of America's war on terrorism is a euphemism for a war on the Arab/Islamic world" (xii). "Ethiopia's Emperor Haile Selassie was a coward" (xiii). "African philosophy is the hermeneutics of the post-colonial situation" (xvi).

Although these are interesting claims which may even be true; they are controversial and, hence, require argumentation. They are, however, not the only ones in the book. According to Serequeberhan, the history of philosophy is best seen as an attempt to provide a theory for European colonialism (12). He notes the racism in the writings and thoughts of David Hume, John Locke, Immanuel Kant, George W.F. Hegel and Karl Marx; and how they have been embraced by some Africans and, consequently, made Africa either dependent on the West or its servant.

South Africa, like much of Africa before, according to Serequeberhan's more recent example, is nostalgic about colonialism (30). He quotes Patrick Bond who reports (in a March 2004 edition of Monthly Review) that "the number of black people who believe life was better under the apartheid regime is growing" (ibid.). While that is true, as it is in other parts of Africa, it is insufficient to support a claim of "nostalgia for the colonial era" (ibid.). First, blacks who subscribe to such views are, as far as I now, in the minority, even if Patrick Bond is right in his claim that this minority is growing. Secondly, they tend to be selective in what they are nostalgic about; the level of corruption or the relative lack of it, in colonial times as compared to post-colonial times, being a case in point.

Journal of World Philosophies 2 (Summer 2017): 195-197 
Serequeberhan may be right in pointing out the differences between the West and Africa with regard to the history of modernization. Much of Africa's modernization, he points out, is the result of Western contact and conquest; rather than the result of local conditions in Africa. This, for Serequeberhan, means that we have to reverse the colonial process and initiate economic changes that are democratic in the sense of being directed and managed by the African people (32). "The aim in all of this," he writes, "is not to reject the West" (35). "Nor is it merely to embrace our indigenousness," he adds (ibid.). "Our objective," he continues, "is to cultivate a synthesis and, in doing so, displace the ideas and concepts-the prejudices and presuppositions in and through which Western hegemony holds us captive" (ibid.).

This is a laudable goal. However, I am not sure it follows from the history of modernization. There are many models and lessons on modernization that can be used here, with different conclusions. Take Japan and Thailand, for example. The problem is that one can always find differences to justify exceptions or objections when it comes to the use of models with which to compare Africa's modernization and draw appropriate lessons.

For me, the argument must be drawn from political philosophy rather than epistemology (of imperialism) as Serequeberhan suggests (ibid.). By "the epistemology of imperialism," he means the assumptions that support Western beliefs; namely, Western ideas and concepts as well as premises and biases (ibid.). A government is not for its own sake but (for) the people or nation, particularly if it is intended to be democratic as most African States profess. This assumption suggests, if we accept it, that governmental economic, social and political processes should be dictated by the needs and benefits of its people. How we implement or achieve these goals, however, is another issue. One could go in a socialistic or capitalistic direction, neither of which is resolved by my argument or Serequeberhan's.

In my opinion, it does not help to generalize about labels or use them as substitutes for arguments. We must, thus, question the soundness of arguments of this sort:

Just as, in the past, Christianity and civilization served the purposes of conquest and colonialism, in like manner, today 'good governance,' 'global/regional stability,' 'food aid,' 'development aid,' 'modernization,' 'economic growth,' 'the fight against terrorism,' 'human rights,' 'women's rights,' 'the rights of minorities,' 'democracy,' 'the rule of law,' and so on are the code-words implicitly linked to the setup in and through which the West holds us captive (ibid.).

For reasons alluded to above, which are different from Serequeberhan's, I agree that "The challenge for African philosophy is to think beyond these snares" (ibid.). I do not, however, think that the task of contemporary African philosophy is, in Serequeberhan's opinion, "to re-imagine-invent, rediscover, retrieve-the lost possibilities that were, at one time, the raison d'etre of the independence struggle" (36). That is a task for psychology and sociology and, maybe, ideology.

Philosophy is a critique of those things; namely psychology and sociology and ideology, including the natural sciences which are burdened with discovering the facts. While a critique of what Serequeberhan calls "the prejudices and presuppositions that sustain the hegemonic hold the West has over us," is a task for African philosophy and, hence, one of its challenges, I do not think it is the main one as Serequeberhan does. "The challenge for African philosophy," he writes, "is to persuasively think through the questioning of this 'hierarchy,' the questioning of the prejudices and presuppositions that sustain the hegemonic hold the West has over us" (37). On this conception, African philosophy becomes narrowly political and reactionary. Further, it does not distinguish between the sciences—-such as psychology, sociology and political science—and philosophy.

African philosophy, like European philosophy, must first be considered philosophy, a second-order discipline which reflects on arguments, and not as a science which discovers facts. That conception is apparent in the earlier part of the book, where Serequeberhan writes that "Philosophy is the practice of reflectively exploring grounding concerns that originate in specific cultures/regions" (11). He adds that "To speak of 'European' or 
'African' philosophy is to indicate the particular culture/region in and out of which 'a specific type of intellectual activity (the critical examination [interpretative exploring] of fundamental problems)' is being actuated" (ibid.). Unfortunately, that view of philosophy, in general, and African and European philosophies, in particular, seems to disappear as the book proceeds.

Further, Serequeberhan does not seem to see much difference between the presidents of the United States of America; not even between George W. Bush and Barack Obama; because "in Kant's words, the United States 'is a judge of its own case' precisely because, as Bush tells us, it acts based on 'military strength beyond challenge" (62). He adds that "for President Bush as for President Obama—and all U.S. presidents since 1945 and before- the unchallengeable might of the United States is and has been the ground of its relations with the rest of the world" (ibid.). It may be a dominant factor in America's relations with the rest of the world. I doubt that it is the only factor and that it is as dominant in Bush's policies as in Obama's (ibid.).

For Serequeberhan, Gadamer-unlike other European philosophers-is more inclusive and, thus useful for contemporary African philosophy (74). Fanon and Cabral as well as Cesaire are forerunners of the practice of contemporary African philosophical hermeneutics (94); not Gobineau or Senghor whom, he claims-falsely, I think — that nobody today takes seriously (118).

Serequeberhan's main claim is that there are shared themes or concerns in Continental and African philosophies, which for me, goes without saying, given that they are both philosophy attempting to address the fundamental questions about life and the universe. However, this claim may bear reiteration given that racism continues to dominate in the writings of some famous European philosophers.

In doing this, Serequeberhan claims to be responding to Fanon's call to develop a new kind of thinking motivated by "global solidarity in the common concerns that constitute our mutual humanity" (119). That is laudable, but I do not think that it is new. This solidarity has always been at least part of the motivation of African philosophy, see for example Kwasi Wiredu's writings, and I believe of philosophy in general (though it seems to have been distorted by some philosophers, in general, and European philosophers in particular).

Overall, Existence and Heritage is an interesting book that is worth reading. If the aim is to provoke us into debating some of the claims mentioned above or the objective of African philosophy, it does that. If, however, the aim is to convince us to embrace those views embraced by Serequeberhan and enumerated above, I am afraid the book falls short; for the reasons mentioned above.

Safro Kwame is an Associate Professor of Philosophy at Lincoln University in Pennsylvania (USA). His publications include: Readings in African Philosophy: An Akan Collection (Lanham, Maryland: University Press of America, 1995) and "Quasi-Materialism: A Contemporary African Philosophy of Mind" in A Companion to African Philosophy: Blackwell Companions to Philosophy, ed. Kwasi Wiredu (Oxford, UK, Blackwell Publishing Ltd., 2004).

Journal of World Philosophies 2 (Summer 2017): 195-197

Copyright (C) 2017 Safro Kwame.

e-ISSN: 2474-1795 • http://scholarworks.iu.edu/iupjournals/index.php/jwp• doi: 10.2979/jourworlphil.2.1.17 